\title{
Trade, Financial Integration, and Synchronization of Business Cycles in NAFTA Member Countries
}

\begin{abstract}
Piotr Misztal*
The aim of the study was to analyze the impact of trade integration (international trade) and financial integration (international capital flows) on the synchronization of business cycles in member countries of the North American Free Trade Agreement (NAFTA) during the 1995-2013 period. Pursuant to the adopted hypothesis, international trade and international capital flows were significant factors in determining the degree of synchronization of business cycles in the examined integrated group. It was international trade that determined the convergence of business cycles in NAFTA to a most significant degree. This was consistent with the results of research carried out by J. Frankel and A. Rose (1998). Moreover, the influence of mutual trade and inter-country capital flows on the synchronization of business cycles of the countries depended on not only the intensity of trade and capital, but mainly on the structure of the trade and capital flows. The research results have important implications in terms of the formation and functioning of integration groups bringing together countries with different levels of economic development. The analysis results also play an important role in the context of the future Polish membership in the euro area. The results of this research have important implications with respect to the formation and functioning of integrated groups bringing together countries of differing levels of economic development. Analysis results also play an important role in the context of the future Polish membership in the euro zone.
\end{abstract}

Keywords: foreign trade, foreign investment, business cycle.

Submitted: 03.03.2015 | Accepted: 09.11.2015

\section{Integracja handlowa i finansowa a synchronizacja cykli koniunkturalnych w krajach członkowskich NAFTA}

Celem badań byta analiza oddziaływania integracji handlowej (handlu międzynarodowego) i integracji finansowej (międzynarodowych przeplywów kapitałowych) na synchronizację cykli koniunkturalnych w krajach cztonkowskich Pótnocnoamerykańskiej Strefy Wolnego Handlu (NAFTA) w okresie 1995-2013. Zgodnie z przyjęta hipoteza badawcza międzynarodowe obroty handlowe oraz międzynarodowe przeplywy kapitatowe byly istotnymi czynnikami determinujacymi stopień synchronizacji cykli koniunkturalnych $w$ analizowanym ugrupowaniu integracyjnym. W największym stopniu handel międzynarodowy determinowat stopień zbieżności cykli koniunkturalnych $w$ krajach NAFTA, co byto zgodne z wynikami badań przeprowadzonymi przez J. Frankel i A. Rose (1998). Co więcej, wplyw handlu wzajemnego

\footnotetext{
Dr hab. Piotr Misztal, prof. UJK - The Jan Kochanowski University (JKU) in Kielce, The Faculty of Management and Administration.

Mailing address: The Jan Kochanowski University (JKU) in Kielce, The Faculty of Management and Administration, 21 Świętokrzyska St., 25-406 Kielce; e-mail: pmisztal@ujk.edu.pl.
} Ministry of Science
and Higher Education Republic of Poland
The creation of the English-language version of these publications is financed in the framework of contract No. 768/P-DUN/2016 by the Ministry of Science and Higher Education committed to activities aimed at the promotion of education. 
krajów oraz wzajemnych przepływów kapitałowych na synchronizację cykli koniunkturalnych krajów zależat nie tylko od intensywności wymiany handlowej i kapitałowej, ale przede wszystkim od struktury obrotów handlowych $i$ kapitatowych. Uzyskane wyniki badań maja istotne implikacje $w$ kontekście możliwości tworzenia i funkcjonowania ugrupowań integracyjnych skupiających kraje o różnym poziomie rozwoju gospodarczego. Wyniki analizy odgrywaja także ważna rolę $w$ kontekście przyszłego czlonkostwa Polski w strefie euro.

Słowa kluczowe: handel zagraniczny, inwestycje zagraniczne, cykl koniunkturalny.

Nadesłany: 03.03.2015 | Zaakceptowany do druku: 09.11.2015

JEL: F15, F21, F23

\section{Introduction}

Analysis of the level of synchronization of business fluctuations in economies is a key matter in discussions relating to the processes of the economic integration of countries today. Particularly, the interests of economists are tied to questions of analysis of occurrences of processes of convergence (merging) and divergence (parting) of business cycles within the framework of various integrated groups. It is for this reason that the objective of research was an analysis of the impact of international trade and international capital flow on the synchronization of business cycles in member states of the North American Free Trade Agreement (NAFTA) over the years 1995-2013. In line with the assumed hypothesis, international trade and international capital flow are significant factors determining the level of synchronization of cycles in the examined countries. The analysis applied research methods based on an overview of literature on macroeconomics and international finance as well as econometric methods. In the theoretical section, conducted research was mainly based on an analysis of foreign topical literature (especially American, British, and German publications), while the empirical part centered on the results of empirical analyses conducted by foreign researchers. Additionally, the empirical section includes proprietary econometric studies using autoregression models. Statistical data used in the econometric studies came from the statistical databases of the United Nations Conference on Trade and Development (UNCTAD). All accumulated statistics had an annual frequency and encompassed the period from 1995 to 2013.

\section{Theoretical Aspects of the Examined Phenomenon}

The level of synchronization of the business cycles of countries or regions is defined as the convergence of rates of economic development over time as seen in correlation to the cyclic component of the real GDP. The degree of synchronization of business cycles is determined by many factors of endogenic character. Among the most important endogenic factors are intensity of trade, degree of similarity of economic structures, degree of similarity of monetary and fiscal policy, and level of financial integration (Lubiński, 2007).

In line with the theoretical view, a dual influencing of trade integration on the correlation of business cycles may occur. On the one hand, if the dominant factor behind a country's business situation is the demand channel, then growth in trade integration among countries may work to increase the level of correlation of the business cycles of the economies. On the other hand, if the dominant force acting on the business cycle consists of factors linked with a given industry, then growth in trade among countries may lead to a decrease in the level of correlation of business cycles or to its increase, depending on the importance of intra- and inter-industry trading. If inter-industry turnover dominates in the exchange between countries, then the growth in specialization in various branches of industry causes the influence of trade integration on the synchronization of business cycles to be negative. However, if intra-industry trade is dominant in country turnover, then the structure of goods traded in the analyzed countries is similar, which may result in a positive impact of trade integration in the synchronization of business cycles.

Wydział Zarządzania UW ～DOI 10.7172/1733-9758.2016.20.7 
Figure 1. Channels of Influence of International Trade Intensity on Business Cycle Synchronization

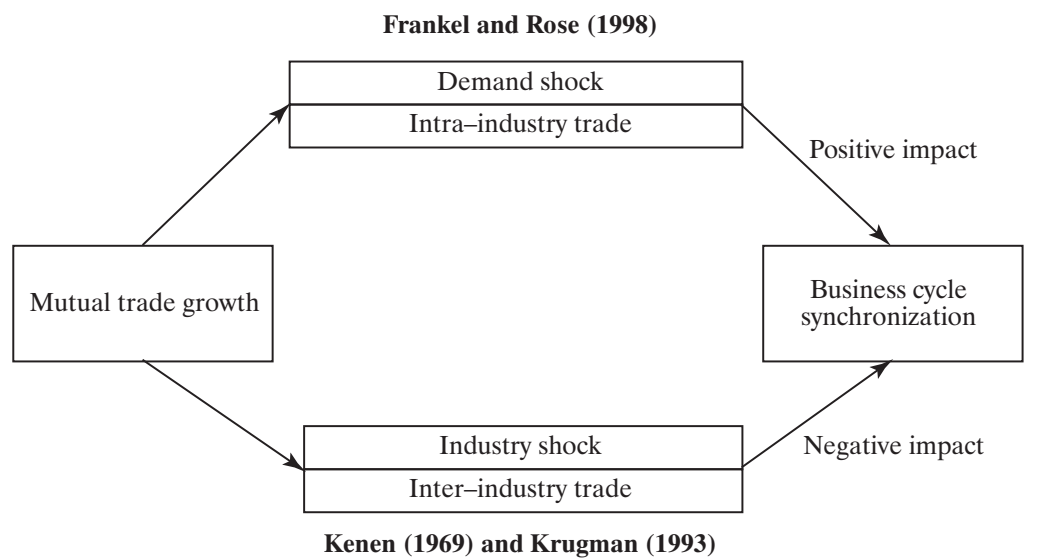

Source: Rana, Cheng, and Chia (2011).

Growth in mutual trade leads to increased convergence of business cycles only when this is a case of intra-industry exchange leading to increased complementarity of the economic structures of the countries that brings about the appearance of symmetrical economic shocks. A similar situation occurs in cases of foreign investment. Specifically, growth in foreign investment causes increased synchronization of business cycles only when the foreign investments directly result in an increase in the level of complementarity of economies. In the opposite case, growth in mutual trade and capital exchange may bring about specialization in manufacturing and trade as well as cause the occurrence of frequent idiosyncratic (asymmetric) shocks.
Since the intensity of intra-industry trade, the volume of direct foreign investments, and the level of technological specialization are dependent on the level of development of the collaborating countries, the influence of trade and capital turnover on the synchronization of the business cycles of collaborating countries is dependent on the level of their economic development.

The results of theoretical-empirical studies show significant implications for the economic policies of countries on differing levels of economic development. First and foremost, the visible trend in the direction of increased intensity of international flows of direct foreign investment results in ever-increasing synchronization in business cycles, primarily in economi-

Figure 2. Channels of Influence of Foreign Investment on Business Cycle Synchronization

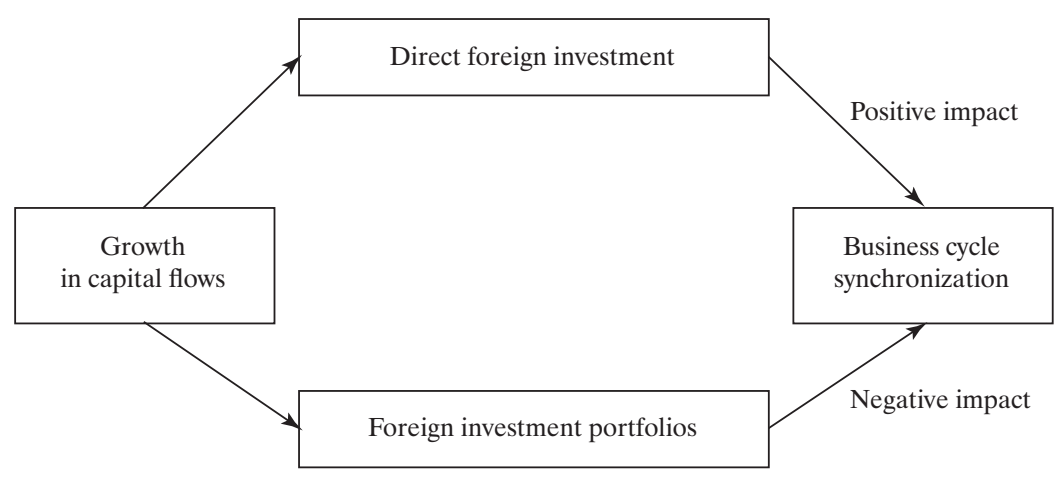

Source: Own development. 
cally highly-development countries, but also, albeit to a significantly lesser degree, in developing and transforming countries. It is for this reason that the economic authorities of countries should pay special attention to the flows of direct foreign investment as the most important channel for the transmission of business changes on an international scale in economically highly-developed countries.

On the other hand, in the case of countries that are developing or transforming, the most important channel bringing about business fluctuations on an international scale continues to be foreign trade, especially intra-industry trade. Thus, in the case of this group of countries, economic decision-makers should have an awareness of the importance of intra-industry trading as the main channel for the transmission of economic shocks on an international scale.

Thus, research results suggest that the beneficial impact of trade integration on the similarity of business cycles is smaller than had previously been thought. One possible explanation for this state of affairs is the fact that foreign trade leads to the transfer of business cycles in a situation of the occurrence of common shocks. However, greater financial integration resulting from growing flows of direct foreign investment plays a role in greater synchronization of business cycles among interested countries. This means that efforts on the part of the state leading to the attracting of direct foreign investment go hand in hand with an increase in the convergence of business cycles (Yetman, 2011).

\section{Trade and Capital Flows vs. Business Cycle Convergence in Light of Selected Empirical Analysis}

Empirical studies on the impact of foreign trade and foreign investment on the synchronization of business cycles in developing and transforming countries as well a economically-developed ones suggest that growth in mutual trade and capital turnover does not necessarily lead to increased synchronization of business cycles in the analyzed economies. The impact of trade and capital flows in countries on the synchronization of their business cycles is not only dependent on the intensity of trade and capital exchange, but primarily on the structure of trade and capital turnover (Kalemli-Ozcan et al., 2013).

Polish economic literature lacks any comprehensive analyses on the influence of international flows in trading and capital on the convergence of the business cycles of mutually collaborating economies. Only a few domestic analyses primarily concentrate on studying the impact of foreign trade in goods on the synchronization of business cycles in the member states of the European Union. On the other hand, in world topical literature, research involves the influence of foreign trade and foreign investment on the convergence of business cycles and mainly looks at economically highly-developed countries (Jansen, Stokman, 2011; Inklaar et al., 2008; Schiavo 2007). For the above reasons, there is a need to comprehensively analyze the question of the influence of trade and financial integration on the convergence of business cycles in both economically developed countries and in developing and transforming countries if for no other reason then as a result of regional economic integration processes that have been growing in strength over recent years throughout the world.

Due to the fact that regional economic integration processes presently touch upon both economically developed countries and those that are developing or transforming, it is becoming vital that comprehensive analyses of questions of the synchronization of business cycles in economies and of their most important determinants in countries on various levels of economic development be conducted. Moreover, an analysis of matters related to the most important factors determining the phenomenon of business cycle synchronization is becoming exceptionally timely and important due to the gradual shift in the "center of gravity" of international trade and capital flows from highly-developed economies to the traditionally understood "Global Triad" of developing economies such as China, India, and Brazil.

De Haan et al. (2005), in analyzing links between the intensity of international trade and the synchronization of business cycles for twenty-one OECD member states over the 1970-2003 period, confirmed the positive impact of the intensity of international trade on the synchronization of business cycles. However, this effect turned out to 
be significantly lesser than suggested by J. Frankel and A. Rose (1998).

The results of empirical research also demonstrated that trade integration was the main factor in the synchronization of business cycles in Islamic countries as well, especially over the 1990-2005 period. Moreover, the similarity of fiscal and monetary policy as well as the similar economic structures of the countries had a significant and positive impact on the synchronization of business cycles (Karimi and Pirasteh, 2009).

Calderón et al. (2002) analyzed the impact of the intensity of foreign trade on the synchronization of business cycles in 147 countries over the years 1960-1999. The results of the conducted research indicated that countries with a higher intensity of bilateral trade were characterized by a greater degree of synchronization of business cycles. At the same time, the influence of trade integration on the synchronization of business cycles was greater in economically highly-developed countries than in developing countries. What is more, the impact of the intensity of trade on business cycle correlation was lower in response to a higher level of asymmetry of production structures among the examined countries.

For their part, the results of empirical analyses conducted by Shin and Wang (2003) on twelve East Asian countries demonstrated that intra-industry trade was the main channel through which the synchronization of the business cycles of those economies took place. However, an overall increase in international trade alone does not have to lead to increased synchronization of business cycles. This situation is caused by the fact that growth in total trade among countries is most often accompanied by the development of inter-industry exchange, which, in its turn, leads to specialization and the differentiation of the manufacturing structures of the various countries.

Thus, the decided majority of conducted empirical analyses indicates that the impact of increased trade among countries on the synchronizing of the business cycles of those countries is not only dependent on the intensity of trade links among the countries, but also on their trade structure. Specifically, if trade among the countries is dominated by intra-industry exchange, symmetrical shocks should be expected and therefore greater synchronization of the business cycles of those countries. On the other hand, if inter-industry trade is dominant in mutual trading, what should be expected then is the more frequent occurrence of asymmetric shocks and lesser synchronization of business cycles (Kose and Yi, 2005).

Jansen and Stokman (2011), in analyzing the experience of Australia, Canada, France, Germany, Italy, Spain, Great Britain, and the United States over the years 1982-2010, demonstrated that greater synchronization of business cycles was accompanied by a more intense flow of direct foreign investment over the 1995-2010 period. What is more, the study authors disclosed the fact that the more intense the flow of direct foreign investment was accompanied by a greater susceptibility of those economies on delayed side effects originating from abroad.

The results of studies conducted by Devereux and Yetman (2010) as well as Devereux and Sutherland (2011) indicated that the level of synchronization of business cycles is also dependent on the type of financial integration found between the countries. In as much as greater integration of the bond market leads to lower correlation of business cycles, growing integration of stock markets leads to the international transmission of technological shocks, which causes greater convergence in business fluctuations.

For their part, Boldrin and Levin (2001) analyzed the impact of technology on changes in the business cycle. The results of conducted research disclosed a significant impact of technology on the course of business cycles. Specifically, new technology introduced to the market replaces old technologies. This causes an economy facing such a situation to start going into recession. Recession occurs when a new technology is developed. However, when the process of introducing new technologies ends, the economy again begins to expand. The period of expansion takes place up to the moment when the applied technology is replaced by a new one. The identified dependencies mean that the expansion phase is longer than the recession phase. Thus, Boldrin and Levine (2001) maintain that technology is the driving force behind business cycles. 


\section{Research Methodology and the Results of the Proprietary Analysis}

A proprietary model was used to measure the impact of trade and capital (financial) integration on the synchronization of business cycles in the NAFTA member states. It is presented in the form of the following formula:

$\operatorname{Corr}_{i j t}=c+\alpha T I I_{i j t}+S e_{i j t}+I I I_{i j t}+S i_{i j t}+\varepsilon_{i j t}(1)$

Where:

Corr $_{i j t}$ - synchronization of the business cycles of countries $i$ and $j$ over period $t$;

$T I I_{i j t} \quad$ - trade intensity index of countries $i$ and $j$ over period $t$;

$S e_{i j t}$ - trade complementarity index of countries $i$ and $j$ over period $t$;

$I I I_{i j t}$ - investment intensity index of countries $i$ and $j$ over period $t$;

$S i_{i j t} \quad$ - investment complementarity index of countries $i$ and $j$ over period $t$;

$c$ - equation absolute term;

$\varepsilon_{i j t} \quad$ - random component.

Measurement of the level of synchronization of business cycles of the countries was accomplished using the Business Cycle Synchronization (BCS) index as developed by Frankel and Rose (1998) as well as Akin (2006). It is expressed using the following formula:

$$
B C S_{i j}=\frac{\operatorname{cov}\left(y_{i}^{c}, y_{j}^{c}\right)}{\sqrt{\operatorname{var}\left(y_{i}^{c}\right) \operatorname{var}\left(y_{j}^{c}\right)}}
$$

Where:

$B C S_{i j}$ - business cycle synchronization index of countries $i$ and $j$;

$y_{i}^{c} \quad-$ logarithm for the real growth of the gross domestic product of country $i$ after eliminating trend using the Hodrick-Presscott filter;

$y_{j}{ }^{c} \quad-$ logarithm for the real growth of the gross domestic product of country $j$ after eliminating trend using the Hodrick-Presscott filter.

A positive value of the BCS index indicates the presence of synchronization of business cycles between two countries $-i$ and $j$. However, a negative value of the BCS index means an absence of synchronization between $i$ and $j$.
In its turn, the intensity of trade is measured using the Trade Intensity Index (TII) as constructed by P. Drysdel and R. Garnaut (1993) as well as A.J. Yeats (1997), and presented in the following formula:

$$
T I I_{i j}=\frac{\left(\frac{X_{i j}}{X_{i w}}\right)}{\left(\frac{M_{j w}}{M_{w w}}\right)}
$$

Where:

$\left(X_{i j} / X_{i w}\right) \quad$ - ratio of exports from country $i$ to country $j$ to the total export of country $i$;

$\left(M_{j w} / M_{w w}\right)$ - ratio of total imports to country $j$ to total world imports.

The Trade Intensity Index is used to calculate if the value of trade between two countries is larger or smaller than might be expected on the basis of their importance in world trade. This index may take on a value that is greater than or smaller than one. An index value that is higher (lower) than one means that bilateral trade is larger (smaller) than expected, taking into account the importance of the partner country in world trade.

On the other hand, the economic complementarity of countries and the intensity of intra-industry trade are shaped by the level of the match in the structure of export supply to the structure of import demand of the countries. This is a matter of the Complementarity Rate of the Exporter ( $\mathrm{Se}$ ), which is the sum of the absolute values of the difference between share in imports and exports (using the three-figure SITC classification) in examined countries divided by two.

$$
S e_{i j}=1-\frac{\sum_{i}\left|E_{i k}-M_{j k}\right|}{2}
$$

Where:

$S e_{i j}$ - trade complementarity index of exporter $i$ as compared with importer $j$;

$E_{i k}$ - share of merchandise group $k$ in total exports of country $i$;

$M_{j k}$ - share of merchandise group $k$ in total imports of country $j$.

The Complementarity Rate of the Exporter may take on a value of between zero and one. 
A zero rate means that there is no connection between the structure of exports of country $i$ and the structure of imports of country $j$. In its turn, a rate equal to one indicates a perfect match between the export and import structures of the examined countries.

Furthermore, the investment intensity of countries is measured using the Investment Intensity Index (III) as presented using the formula below:

$$
I I I_{i j}=\frac{\left(\frac{O U T_{i j}}{O U T_{i w}}\right)}{\left(\frac{I N W_{j w}}{I N W_{w w}}\right)}
$$

Where:

$$
\begin{aligned}
\left(O U T_{i j} / O U T_{i w}\right)- & \text { ratio of the outflow of } \\
& \text { capital from country } i \\
& \text { to country } j \text { to the total } \\
& \text { investment outflow } \\
& \text { from country } i \\
\left(I N W_{j w} / I N W_{w w}\right)- & \text { ratio of the inflow of } \\
& \text { capital from country } \\
& j \text { to total world capital } \\
& \text { inflow. }
\end{aligned}
$$

The Investment Intensity Index is used to define if the value of the capital flows between two countries is greater or lesser than might be expected on the basis of their importance in world capital flows. This index may take on a value that is greater than or less than one. An index value greater (less) than one means that bilateral capital exchange is greater (less) than expected, bearing in mind the importance of the partner country in world capital turnover.

On the other hand, the Complementarity Rate of Investment $(\mathrm{Si})$ provide information regarding the importance of mutual exchange in direct foreign investment in the examined economies and calculated it using the following formula:

$$
S i_{i j}=\frac{F D I O U T_{i j t}+F D I I N W_{i j t}}{G D P_{i t}+G D P_{j t}}
$$

Where:

$S i_{i j}$ - Complementarity Rate of Investment of country $i$ with respect to country $j$ over period $t$;
FDIOUT $_{i j t}$ - value of the outflow of direct foreign investments from country $i$ to country $j$ over period $t$;
$F D I I N W_{i j t}$ - value of the inflow of direct foreign investments to coun- try $i$ from country $j$ over period $t$;
$G D P_{i t} \quad$ - value of the gross domestic product of country $i$ over period $t$;
$G D P_{j t} \quad$ - value of the gross domestic product of country $j$ over period $t$;

The greater the level of the Complementarity Rate of Investment of the countries, the relatively greater the importance of mutual flows of direct foreign investment for the economies of the examined countries.

All of the above-listed variables used in estimating model parameters had an annual frequency and encompassed the period from 1995 to 2013 . In line with the figure below, the values of the synchronization coefficients for business cycles in the United States, Canada, and Mexico were positive over the whole of the examined period. This signifies a relatively high synchronization of business cycles among those economies. What is more, the level of convergence of business cycles did indeed increase as of 2008 (Figure 4).

In their turn, the highest values of the coefficients for trade intensity and complementarity, and investment intensity and complementarity of NAFTA member states appeared at the turn of the last and present centuries after which they significantly fell. This bears witness to a decrease in the level of trade and financial integration among NAFTA countries.

The decreasing level of trade and financial integration among NAFTA member states was a consequence of a geographical reorientation in trade and financial exchange, mainly on the part of the United States and Canada with respect to Asian countries, especially China and India.

Priori to making the estimates for the model explaining the influence of trade and capital integration on the synchronization of business cycles in NAFTA member countries, it was necessary to first define the stationarity of the applied time series. Failure to take into account the stationarity 
Figure 3. Business Cycle Synchronization Index (BCS) for the United States, Canada, and Mexico over the 1995-2013 Period

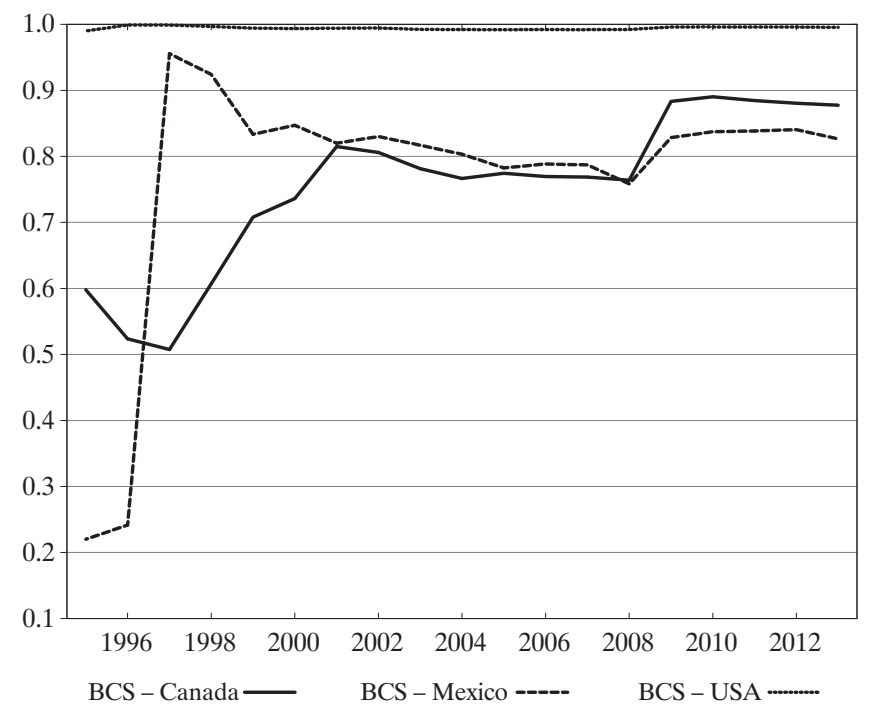

Source: Own development based on UNCTAD data.

Figure 4. Trade Intensity Index, Trade Complementarity Index, Investment Intensity Index, and Investment Complementarity Index for NAFTA Countries for the 1995-2013 Period

TII

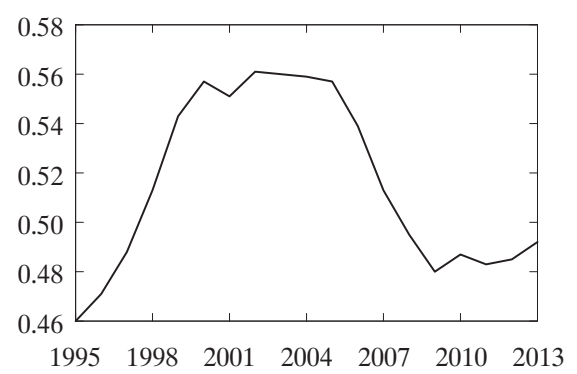

III

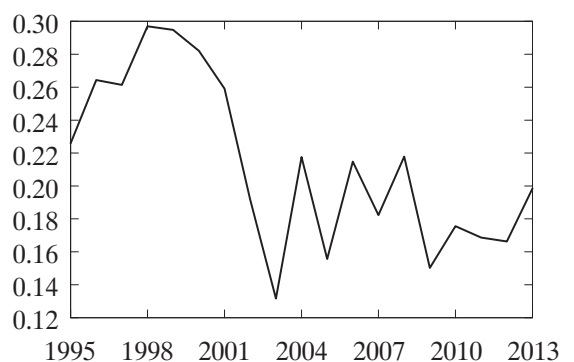

Se

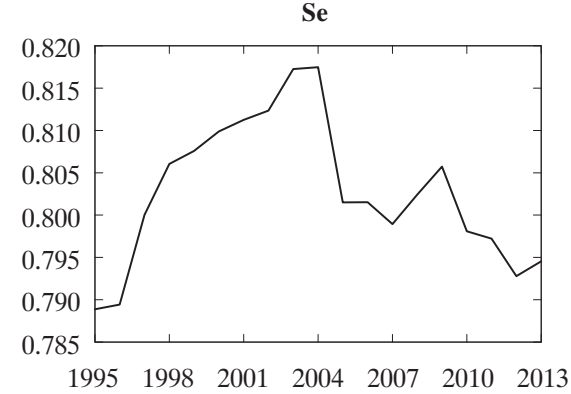

$\mathrm{Si}$

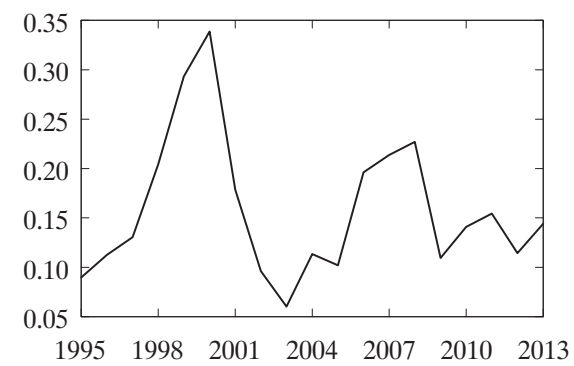

Source: Own development based on UNCTAD data.

Wydział Zarządzania UW DOI 10.7172/1733-9758.2016.20.7 
of time series could result in the occurrence of spurious regression among the variables. The Augmented Dickey-Fuller (ADF) test was used to this end.

The results of the ADF test indicated the occurrence of time series with integration magnitudes of 0,1 , and 2 . The relevant ADF test results are presented in the table below.

Table 1. Analysis results for Stationarity of Individual Time Series of the VAR Model

\begin{tabular}{|c|c|}
\hline Time Series & $\begin{array}{l}\text { Integration } \\
\text { Magnitudes }\end{array}$ \\
\hline \begin{tabular}{|l}
$B C S-$ Business Cycle \\
Synchronization index
\end{tabular} & $I(I)$ \\
\hline TII - Trade Intensity Index & $I(1)$ \\
\hline $\begin{array}{cc}\text { Se } & \text { - Trade Complementarity } \\
\text { Index }\end{array}$ & $I(2)$ \\
\hline III - Investment Intensity Index & $I(I)$ \\
\hline $\begin{array}{l}S i \quad-\text { Investment } \\
\text { Complementarity Index }\end{array}$ & $I(0)$ \\
\hline
\end{tabular}

Source: Own development.

Lack of stationarity of most of the used time series taken into account in the model forced the modification of the functional forms of the model. This modification involved the replacement of the magnitude of the analyzed variables by their first difference in the case of variables with a degree of integration equal to one and by their successive differences in the case of variables with a degree of integration equal to two.

The analysis also assumed an appropriate period of delays between the explana- tory variables and the explained variable. Selection of magnitude of delays was made on the basis of the results of the information criteria of the Akaike, SchwartzBayesian, and Hannan-Quinn model.

The analysis assumed an appropriate period of delays between the explanatory variables and the explained variable (two years). Selection of the magnitude of delay was in agreement with the results of the information criteria of the Akaike, Schwartz-Bayesian, and Hannan-Quinn model. According to those criteria, it was the model with two delays that had the greatest information capacity.

The next stage of the analysis was the estimation of the equation (1) using the Vector Autoregression Model. The main advantage of this estimation method is that in its case the given phenomenon is analyzed using a set of equations that, in line with the Sims postulate (1980) simultaneously eliminated the problem of exogeneity of explanatory variables.It is on the basis of data presented in the above table that it is possible to state that the greatest, positive impact on the level of synchronization of business cycles in the member countries of NAFTA over the 1995-2013 period was that of the intensity of trade and the trade complementarity of member countries. At the same time, the smallest, although still positive impact on the convergence of business cycle was that of the intensity of investment and the investment complementarity of the examined countries. Thus, it is the size and structure of mutual trade among NAFTA member countries that mainly determined the degree of synchronization of their business cycles.

Table 2. Akaike, Schwartz-Bayesian, and Hannan-Quinn Information Criteria Results

VAR system, maximum magnitude of delay 2

An asterisk $(*)$ indicates the best (the minimal) value for the relevant information criteria, $\mathrm{AIC}=$ Akaike criteria, $\mathrm{BIC}=$ Schwartz-Bayesian criteria, and $\mathrm{HQC}=$ Hannan-Quinn criteria

\begin{tabular}{cccccc} 
Delay & loglik & $\mathrm{p}(\mathrm{LR})$ & $\mathrm{AIC}$ & $\mathrm{BIC}$ & $\mathrm{HQC}$ \\
1 & 178.98093 & & -20.530790 & -19.350706 & -20.543360 \\
2 & 224.13104 & 0.00000 & $-23.217472^{*}$ & $-20.857305^{*}$ & $-23.242613^{*}$ \\
\hline
\end{tabular}

Source: Own development. 
Table 3. VAR (Vector Autoregression Model), magnitude of delay 2, and KMNK estimate for 1995-2013 observations

\begin{tabular}{|c|c|c|c|c|c|}
\hline \multicolumn{6}{|c|}{$\begin{array}{l}\text { Confidence logarithm }=224.13104 \text { Covariance matrix determinant }=7.2295 \\
\mathrm{AIC}=-23.2175 \mathrm{BIC}=-20.8573 \mathrm{HQC}=-23.2426 \text { Test portmanteau: } \mathrm{LB}(3 \\
\mathrm{df}=25[0,0000] \\
\text { Equation 1: BCS } \\
\text { HAC standard deviation, widow width } 1 \text { (Bartlett kernel) }\end{array}$} \\
\hline & Coefficient & $S D$ & t-Student & $p$ value & \\
\hline BCS_1 & -0.712297 & 0.0322675 & -22.0748 & $<0.00001$ & $* * *$ \\
\hline BCS_2 & -0.291461 & 0.0219539 & -13.2761 & 0.00004 & $* * *$ \\
\hline TII_1 & 6.73647 & 1.56455 & 4.3057 & 0.00767 & $* * *$ \\
\hline Se_1 & 5.76834 & 1.64896 & 3.4982 & 0.01732 & $* *$ \\
\hline Se_2 & 3.53684 & 1.55683 & 2.2718 & 0.07227 & $*$ \\
\hline III_2 & 0.883612 & 0.233873 & 3.7782 & 0.01291 & $* *$ \\
\hline Si_1 & 0.684662 & 0.15858 & 4.3175 & 0.00759 & $* * *$ \\
\hline \multicolumn{3}{|c|}{ Dependent variable arithmetic mean } & \multicolumn{2}{|c|}{ Dependent variable SD } & 0.218052 \\
\hline \multicolumn{2}{|c|}{ Squared residual sum } & 0.027958 & \multicolumn{2}{|c|}{ Residual SD } & 0.074777 \\
\hline \multicolumn{2}{|c|}{ Coefficient of determination $\mathrm{R}$-squared } & ed $\quad 0.961150$ & \multicolumn{2}{|c|}{ Adjusted R-squared } & 0.891221 \\
\hline \multicolumn{2}{|l|}{$\mathrm{F}(10,5)$} & 12.37014 & \multicolumn{2}{|c|}{$\mathrm{p}$ value for the $\mathrm{F}$ test } & 0.006239 \\
\hline \multicolumn{2}{|c|}{ Residual autocorrelation - rho1 } & 0.219956 & \multicolumn{2}{|c|}{ Durbin-Watson stat. } & 1.430866 \\
\hline
\end{tabular}

Source: Own development.

The successive step of the analysis involved the measurement of the influential force of individual factors determining the level of convergence of business cycle on NAFTA member states. This measurement was conducted using what is known as the impulse response function, which is a function of the reaction of the BCS index on an impulse in the form of a unit change in the delayed index for business cycle synchronization, the trade intensity index, the trade complementarity index, the investment intensity index, and the investment complementarity index.

It was on the basis of the above figures that it was noted that the shock growth on the business cycle synchronization index by one unit in NAFTA member countries resulted in an immediate increase in the BCS index over the first year followed by stabilization after the elapse of five years as of the moment of the shock. The reaction of the business cycle synchronization index to shock in the form of changes in trade intensity is somewhat different. Growth in intensity of trade among member countries of NAFTA led to a gradual growth in the BCS index over the first year successively followed by gradual stabilization after the elapse of the seventh year up as of the moment of the occurrence of the change shock. The situation is similar in the case of the reaction of the BCS index to shock changes in trade complementarity, investment intensity, and investment complementarity in the member states of the North American Free Trade Agreement, where the process of stabilization of the business cycle synchronization index took somewhat longer after the occurrence of the shock.

The last phase of the analysis was the decomposition of the variance of the residual component of the business cycle synchronization index in order to assess the impact of changes in trade and financial integration on change in the BCS index.

The data presented in the above figure make it possible to note that the greatest 
Figure 5. Graph Depicting the BCS Index Impulse Response Function for a One-Time Induced Impulse, and the Unit Change in the Business Cycle Synchronization Index, Trade Intensity Index, Trade Complementarity Index, Investment Intensity, and Investment Complementarity
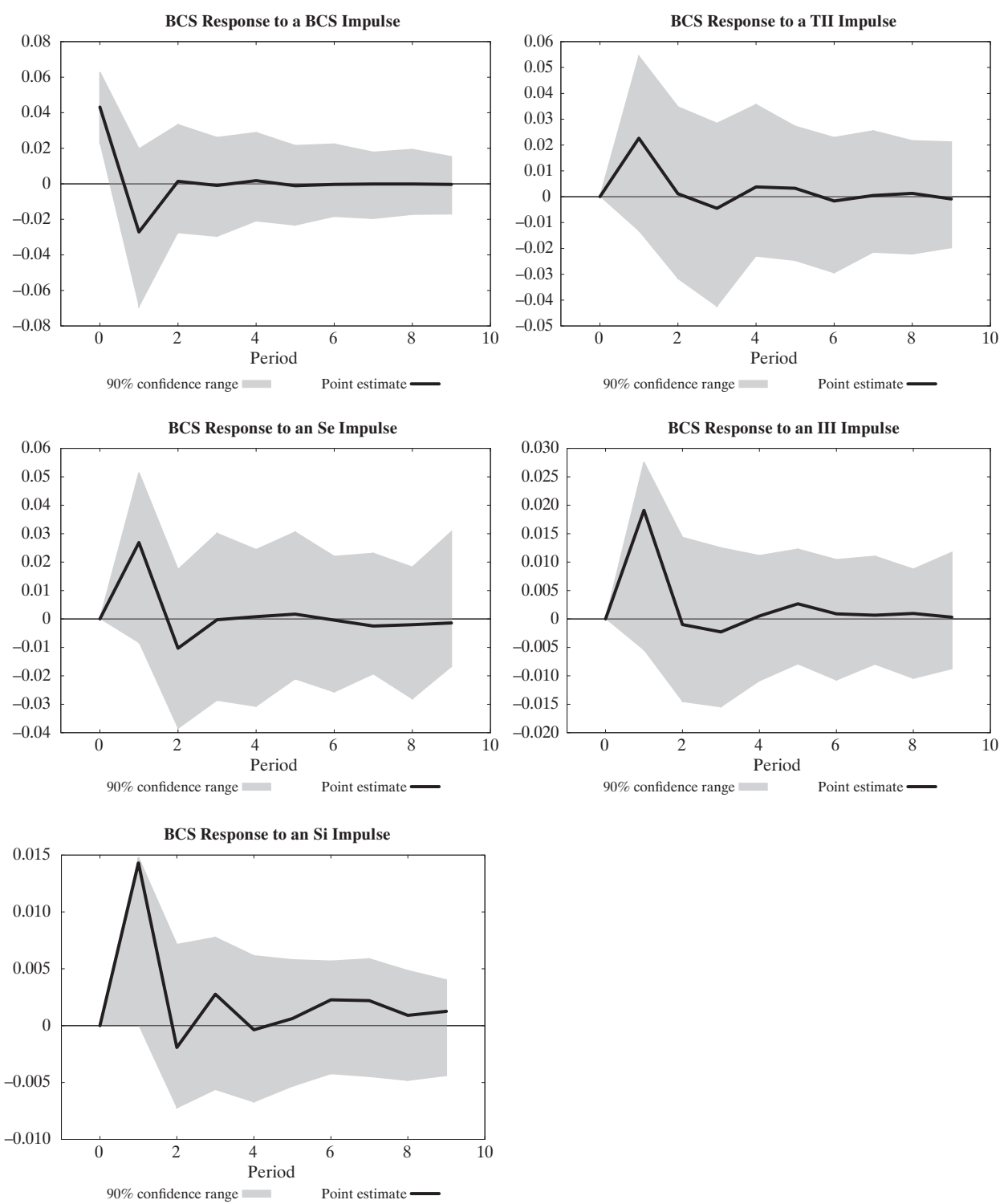

Source: Own development.

degree (approximately 60\%) of change in the business cycle synchronization index in the NAFTA member states is explained by inertia - the delayed business cycle convergence index. In their turn, approximately $20 \%$ of the change in the BCS index was explained by changes in the degree of trade

complementarity, while approximately $10 \%$ of it was the result of change in the trade complementarity index. Changes in the business cycle synchronization index for NAFTA member states was explained to the least degree by changes in the investment intensity and complementarity indexes. 
Figure 6. Decomposition of the Variance in the Residual Component of the Business Cycle Synchronization Index

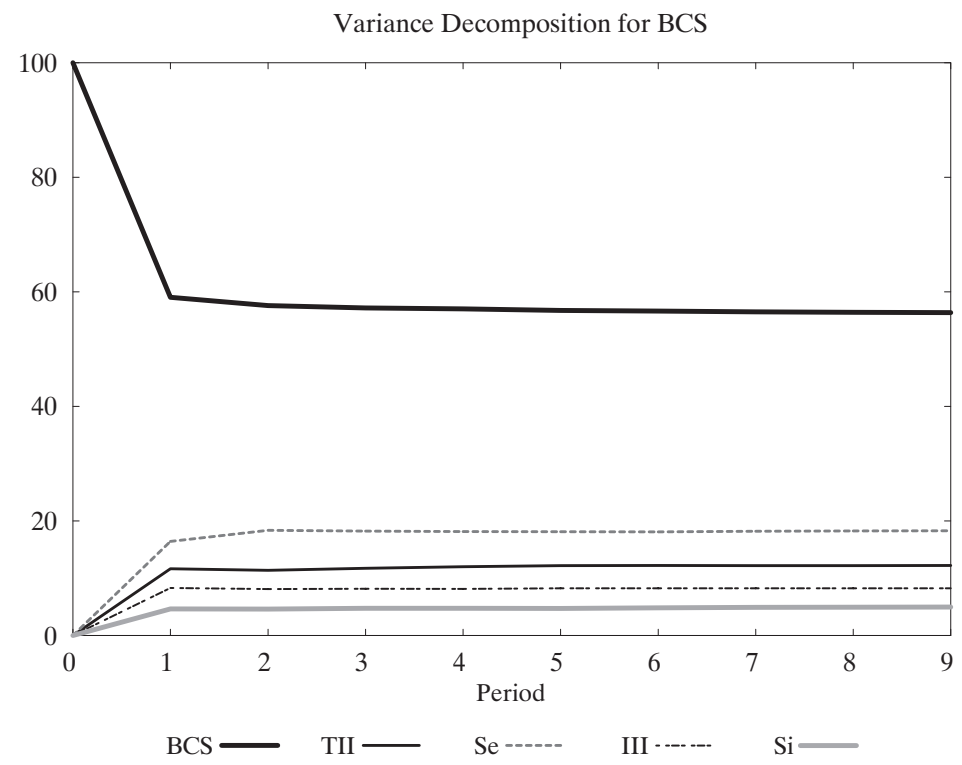

Source: Own development.

\section{Conclusion}

The level of synchronization of business cycles of countries or regions - the convergence of economic growth rates over time - is the correlation of the cyclic component of the real GDP that is determined by many factors that are endogenic in character. This paper analyzed the impact of international trade and international capital flows on the synchronization of business cycles in the member countries of the North American Free Trade Agreement (NAFTA) over the years 1995-2013. The results of analysis identified the greatest and positive impact of trade intensity and trade complementarity in NAFTA member countries on the level of synchronization of their business cycles. At the same time the smallest, though still positive impact on the convergence of business cycles was the result of the investment intensity and investment complementarity of the examined countries.

Study results received have significant implications from the point of view of the possibilities for the establishing and functioning of integrated groups concentrating countries on various levels of economic development. Analysis results also play an important role in the context of Poland's future membership in the Euro Zone. Specifically, since growth in mutual trade and direct foreign investment leads to increased correlation of the business cycles of the economy, costs tied to the lack of autonomous monetary policy in the face of idiosyncratic economic shocks will be lower in the case of Poland's membership in the monetary union. Thus, net benefits for Poland stemming from membership in the monetary union will turn out to be greater under conditions of growing complementarity of the economic structures of Poland and the Euro Zone. For this reason, these research results can serve as an important argument supporting Poland's striving to full membership in the monetary union of European Union member states.

\section{References}

Akin, C. (2006). Multiple Determinants of Business Cycle Synchronization. Washington: George Washington University, Department of Economics.

Boldrin, M. and Levine, D.K. (2001). Growth Cycles and Market Crashes. Journal of Economic Theory, January-February, 96(1-2).

Calderón, C., Chong, A. and Stein, E. (2002). Trade Intensity and Business Cycle Synchronization: Are 
Developing Countries Any Different? Central Bank of Chile Working Papers, 195.

De Haan, J., Inklaar, R.C. and Jong-a-Pin, R.M (2008). Will Business Cycles in the Euro Area Converge? A Critical Survey of Empirical Research. Journal of Economic Surveys, 22.

De Haan, J., Inklaar, R. and Jong-a-Pin, R.M (2005). Trade and Business Cycle Synchronization in OECD Countries: a Re-examination. CESifo Working Paper Series, 1546.

Devereux, M.B. and Sutherland, A. (2011). Evaluating International Financial Integration Under Leverage Constraints. European Economic Review, 55.

Devereux, M.B. and Yetman, J. (2010). Leverage Constraints and the International Transmission of Shocks. NBER Working Paper 16226.

Drysdel, P. and Garnaut, R. (1993). The Pacific: An Application of General Theory of Economic Integration. In: Bergsten, F. and Noland, M. (eds.), Pacific Dynamism and International Economic System. Washington: Institute for International Economics.

Frankel, J. and Rose, A. (1998). The Endogenity of the Optimum Currency Area Criteria. The Economic Journal, 108.

Jansen, J. and Stokman, A. (2011). International Business Cycle Comovement: Trade and Foreign Direct Investment. DNB Working Papers, 319.
Kalemli-Ozcan, S., Papaioannou, E. and Peydró, J.-L. (2013). Financial Regulation, Financial Globalization, and the Synchronization of Economic Activity. The Journal of Finance, 68(3), 1179-1228.

Karimi, F. and Pirasteh, H. (2009). Relationship between Economic Integration and Business Cycle Synchronization. International Journal of Business and Development Studies, 1(1).

Kose, M.A. and Yi, K.M. (2005). Can the Standard International Business Cycle Model Explain the Relation Between Trade and Comovement? Federal Reserve Bank of Philadelphia Working Paper, 05-3.

Lubiński, M. (2007). Międzynarodowy cykl koniunkturalny [The international business cycle]. Contemporary Economics, 1(2).

Rana, P.B., Cheng, T., and Chia, W.M. (2011). Trade Intensity and Business Cycle Synchronization: East Asia vs. Europe. Journal of Asian Economics, 20.

Shin, K. and Wang, Y. (2003). Trade Integration and Business Cycle Synchronisation in East Asia. ISER Discussion Paper, 574.

Sims, C.A. (1980). Macroeconomics and Reality. Econometrica, 1.

Yetman, J. (2011). Exporting Recessions: International Links and the Business Cycle. Economics Letters, 110(1). 